\title{
Epidemiologi ved systemisk sklerose (sklerodermi)
}

\author{
Jan Tore Gran og Øyvind Midtvedt \\ Revmatologisk avdeling, Rikshospitalet-Radiumhospitalet, Oslo
}

\begin{abstract}
ENGLISH SUMMARY
Gran JT, Midtvedt Ø. The epidemiology of systemic sclerosis. Nor J Epidemiol 2008; 18 (1): 64-66.
\end{abstract}

Systemic sclerosis is an inflammatory rheumatic disease affecting small arteries, microvessels and connective tissue. Pathological findings include fibrosis, vasculopathy and production of autoantibodies. Clinically, two distinct subgroups can be identified. Limited cutaneous systemic sclerosis is associated with anticentromere antibodies and the skin lesion never extends proximally to the elbows and knees. Diffuse cutaneous systemic sclerosis exhibits production of anti topoisomerase I antibodies (anti Scl 70) and skin lesion affects also proximal parts of the body. The annual incidence is estimated to 0.2-1.9 per 100000 inhabitants. The prevalence is approximately $7-15$ cases per 100000 inhabitants. Mortality is significantly increased, mainly due to pulmonal arterial hypertension and interstitial lung disease. A possible increased risk of contracting lung cancer is still debated.

\section{DEFINISJON}

Systemisk sklerose ( $\mathrm{SSc}$ ), eller sklerodermi er en generalisert revmatisk sykdom som angriper små arterier, mikrokar og bindevev. De patologiske forandringer omfatter betydelig fibrose og karobliterasjon i hud og multiple indre organer. Forandringene antas å oppstå på grunn av en uttalt fibroblast-dysfunksjon som fører til økt deponering av ekstracellulær matrix, en vaskulær forstyrrelse som gir vevshypoksi og sist en immunrespons kjennetegnet ved endret T- og B-lymfocyttfunksjon og produksjon av autoantistoffer (1).

SSc ble sannsynligvis først beskrevet av Carlo Curzio som i 1753 la frem sykehistorien til en 17 år gammel pasient med generell hudfortykkelse.

\section{KLINISKE MANIFESTASJONER}

Omtrent alle pasienter utvikler typiske hudmanifestasjoner (skleroderma). Disse starter oftest distalt på ekstremitetene med tiltagende stramhet av huden, fett og muskelatrofi og oftest utvikling av kontrakturer. I senstadiene er huden hard og adherent til underlaget.

Hos over $90 \%$ angripes magetarmkanalen hvor dysfagi på grunn av dysmotilitet av øsofagus sees hos nesten alle. Videre opptrer blødninger i ventrikkel (Watermelon stomach), diare, fæcal inkontinens, og malabsorpsjon. Skleroderma nyrekrise med rask utviklende nyresvikt og hypertensjon sees hos noe under en firedel, interstitiell lungesykdom hos omkring $40 \%$ og pulmonal arteriell hypertensjon hos $15 \%$.

Kompromitert mikrosirkulasjon gir Raynaudfenomener, mikroinfarkter på distale deler av ekstremitene, og evt. gangren av fingre og tær. Kutane ulsera sees hos over $50 \%$ av pasientene.

\section{KLASSIFIKASJON}

Systemisk sklerose inndeles i to hovedtyper; begrenset kutan SSc og diffus kutan SSc. Ved den begrensete form (limited) er hudforandringene lokalisert distalt og når ikke proksimalt for albuer og knær. Denne typen SSc er assosiert med anticentromer antistoff og utvikler nesten aldri sklerodermi nyrekrise. Interstitiell lungesykdom og pulmonal arteriell hypertensjon er ikke sjelden. Pasientene har ofte Raynaud-fenomener i lang tid før hudmanifestasjonene opptrer. Tidligere ble betegnelsen CREST-syndrom brukt om begrenset kutan SSc (Calcinose, Raynaud-fenomener, Øsofagus dysmotilitet, Sklerodaktyli og Teleangiektasier).

Ved diffus kutan SSc sees omfattende hudforandringer som strekker seg proksimalt for knær og albuer. Tilstanden er assosiert med anti-topoisomerase I (antiScl 70) og Raynaud-fenomener utvikles gjerne like før, samtidig med eller like etter hudforandringene. Affeksjon av indre organer er hyppig.

\section{DIAGNOSE OG KLASSIFIKASJONSKRITERIER (ACR)}

Diagnosen SSc baseres på typiske hudforandringer, kapillaroskopi og påvisning av autoantistoffer. Til vitenskapelig bruk benyttes ACR (Americal College of Rheumatology) kriteriene (2) hvor hovedkriteriet er hudforandringer (skleroderma) proksimalt for fingrenes eller tærnes grunnledd (MCP/MTP) eller to av: sklerodaktyli, sår eller atrofi av fingertupper og bilateral basal pulmonal fibrose.

\section{Prevalens OG InSIDENS}

Fordi sykdommen er sjelden er det ikke foretatt befolkningsstudier. Informasjon om forekomst har vi fra diagnoseregistre og pasientmaterialer fra sykehus. Disse vil naturligvis omfatte de mer typiske og alvorlige tilfeller, men de mer benigne og atypiske tilfeller underestimeres i slike studier.

På Island er det beregnet en insidens på $0,38 /$ 100 000/år (3) og i Hellas på 1,1/100 000/år (4). En 
sykehusbasert undersøkelse fra Sør-Norge (5) konkluderte med en insidens på 0,2-1,9/100 000/år hvilket altså er noe høyere enn beregninger fra andre europeiske studier.

Det er ikke påvist forskjeller i prevalens mellom ulike land i Amerika og Europa av etiologisk betydning. Forskjellig studiedesign er nok forklaringen til at angivelsene varierer fra 0,7 (Canada) (6) til 15,8 (Frankrike) (7), men de fleste angir fra 7-15/100 000 innbyggere $(3,4,8,9)$. En bemerkelsesverdig høy forekomst er funnet blant nord-Amerikanske Choctawindianere (469/100 000), men noen god forklaring på dette har man ikke (9). Det er usikkert om insidensen er stigende eller fallende. Sykdommen er rapportert både i Afrika og Asia. Det er ikke påvist forskjeller $\mathrm{i}$ forekomst mellom by og bygd (9).

\section{DEMOGRAFI (KJØNN OG ALDER)}

SSc angriper 4-8 ganger så mange kvinner som menn $(4,9)$ og oppstår oftest i 30-60-årene. Den diffuse kutane type sees svært sjelden hos barn og ungdom, og ved barnerevmatologisk seksjon Rikshospitalet har man behandlet under 5 slike barn i løpet av en 20-30 års periode. Hos barn er de lokaliserte former langt vanligere.

\section{MORTALITET OG KREFTRISIKO}

Dødeligheten er økt ved SSc, og det angis en SMR varierende fra 2-4 (10). 5 års overlevelse er omkring $80 \%$ (4), mens 10 års overlevelse varierer fra omkring $60 \%$ (11) til $85 \%$ (12), men om denne er bedret de senere år er uvisst. I en studie fra 1991 var 12 års overlevelse bare $30 \%$ (12), mot 70\% 10 års overlevelse i Hellas i 2005 (9).

Omkring 60-80\% av dødsfallene kan relateres til selve grunnsykdommen $(10,11,13)$. Den økte dødelighet skyldtes tidligere akutt renal krise, men denne tilstand lar seg nå hos de fleste effektivt behandle med angiotensin converting enzyme hemmere (ACE). Etter innføringen av ACE-hemmere var pulmonal arteriell hypertensjon hyppigste årsak til død forårsaket av SSc (11), men også her er dødeligheten redusert på grunn av mer effektiv behandling (prostacyklin analoger og endotelin 1 reseptor antagonister). Overlevelse ved PAH i dag (2005) 1 år etter diagnose er 96\%, og etter 2 år $89 \%$ ved behandling med bosentan mot forventet 69 og 57\% (14).

Den viktigste SSc-relaterte dødsårsak i dag er interstitiell lungesykdom hvor immunosuppressiv behandling ikke synes å kunne redusere dødelighet eller bedre utfallet.

Insidensen av maligne sykdommer er økt ved SSc (RR omkring 2). Det synes å være en bred enighet om at dette først og fremst skyldes økt insidens av lungecancer som oftest sees hos pasienter med ledsagende interstitiell lungesykdom (15-17). SIR for lungecancer ved SSc er 3-16 $(18,19)$. Noen finner assosiasjon til sigarettrøyking (20), andre ikke (19). Det foreligger en viss uenighet om forekomsten av ca. mammae, lymfom og cancer i tunge er økt ved SSc $(10,15,21,22)$.

\section{SAMFUNNSMESSIGE KONSEKVENSER}

SSc er en sjelden sykdom slik at de samfunnsmessige konsekvenser neppe er av stor betydning. Morbiditeten er imidlertid betydelig og nesten alle pasienter med diffus kutan type har betydelig nedsatt livskvalitet og redusert yrkesaktivitet. Behandlingen for de avanserte tilfeller er betydelig men med den lave prevalensen utgjør dette neppe de store kostnader for de fleste revmatologiske avdelinger.

\section{UTFORDRINGER I NORGE}

Som for flere andre multiorgansykdommer er det ingen enighet om hvem som skal ha hovedansvaret for omsorgen av disse pasientene. Pasienter med SSc tas hånd om av både lungeleger, indremedisinere, dermatologer og revmatologer. Det første som bør gjøres er å oppnå en nasjonal enighet om at en enkelt medisinsk spesialitet skal ha hoved- og koordineringsansvaret for denne diagnosegruppen.

Da sykdommen er sjelden bør utredning og behandling av pasienter med diffus kutan SSc sentraliseres til en enkelt nasjonal institusjon. Hele gruppen burde registreres i en database og biobank. Dette vil gi muligheter for internasjonalt samarbeid, medikamentutprøvinger og longitudinelle epidemiologiske studier. Kontinuerlig overføring av kompetanse fra et slikt senter vil kunne bedre diagnostikk og behandling av SSc.

Det finnes per i dag ingen aktiv laboratorieforskning på SSc i Norge. Dette vil kunne igangsettes dersom et senter fikk hovedansvaret for diagnosegruppen. En slik forskning ville kunne nyttes også på andre medisinske områder da SSc innbefatter sentrale patologiske mekanismer som trombose, vaskulopati og fibroseutvikling. Dette sees også ved en lang rekke andre tilstander.

\section{HoVEDBUDSKAP}

- Systemisk sklerose er en sjelden systemisk bindevevssykdom som bør diagnostiseres tidligst mulig.

- Omsorgen for denne pasientgruppen bør organiseres på en måte som sikrer tidlig diagnose, ensartet behandling og standardisert oppfølgning.

- Flere av de alvorlige komplikasjonene (pulmonal arteriell hypertensjon, digitale ulcera og interstitiell lungesykdom) kan i dag behandles mer effektivt enn tidligere.

- Dødelighet og kreftrisiko er økt ved systemisk sklerose. 


\section{REFERANSER}

1. Gran JT, Molberg Ø, Midtvedt Ø. Patofysiologiske aspekter ved systemisk sklerose. Tidsskr Nor Laegeforen 2005; 125: 2622-3.

2. Subcommittee for scleroderma criteria of the American Rheumatism Association Diagnostic and Therapeutic criteria committee. Preliminary criteria for the classification of systemic sclerosis (scleroderma). Athritis Rheum 1980; 23: 581-90.

3. Geirsson AJ, Steinsson K, Gudmundsson, Sigurdsson V. Systemic sclerosis in Iceland. A nationwide epidemiological study. Ann Rheum Dis 1994; 53: 502-5.

4. Alamanos Y, Tsifetaki N, Paraskevi V, Voulgari MD, Siozos C, Kiriaki T, Alexiou GA, Drosos AA. Epidemiology of systemic sclerosis in northwest Greece 1981-2002. Semin Arthritis Rheum 2005; 34: 714-20.

5. Haugeberg G, Brodin C, Johnsen V. Systemisk sklerose. Tidsskr Nor Lageforen 1995; 115: 3619-22.

6. Thompson AE, Pope JE. Increased prevalence of scleroderma in southwestern Ontario: a cluster analysis. $J$ Rheumatol 2002; 29: 1867-73.

7. Le Guern, Mahr A, Mouthon L, Jeanneret D, Carzon M, Guillevin L. Prevalence of systemic sclerosis in a French multi-ethnic county. Rheumatology 2004; 43: 1129-37.

8. Allcock RJ, Forrest I, Corris PA, Crook PR, Griffiths ID. A study of the prevalence of systemic sclerosis in northeast England. Rheumatology 2004; 43: 596-602.

9. Silman A. Scleroderma. In: Silman A, ed. Epidemiology of the rheumatic diseases, 2nd edition. Oxford, 2001: 141-62.

10. Bryan C, Howard Y, Brennan P, Black C, Silman A. Survival following the onset of scleroderma: results from a retrospective inception cohort study of the UK patient population. Br J Rheumatol 1996; 35: 1122-6.

11. Lee P, Langevitz P, Alderdice CA, Aubrey M, Baer PA, Baron M et al. Mortality in systemic sclerosis (scleroderma). Q J Med 1992; 82: 139-48.

12. Simeon CP, Armadans L, Fonollosa V, Vilardell M, Candell J, Tolosa C et al. Survival prognostic factors and markers of morbidity in Spanish patients with systemic sclerosis. Ann Rheum Dis 1997; 56: 723-8.

13. Altman RD, Medsger TA, Bloch DA, Michel BA. Predictors of survival in systemic sclerosis (scleroderma). Arthritis Rheum 1991; 34: 403-13.

14. Mclaughlin VV, Sitbon O, Badesch DB, Barst RJ, Black C, Galie N et al. Survival with first-line bosentan in patients with primary pulmonary hypertension. Eur Respir J 2005; 25: 244-9.

15. Rosenthal AK, Mclaughlin JK, Linet MS, Persson I. Scleroderma and malignancy: an epidemiological study. Ann Rheum Dis 1993; 52: 531-3.

16. Pearson JE, Silman AJ. Risk of cancer in patients with scleroderma. Ann Rheum Dis 2003; 62: 697-9.

17. Simeon CP, Armadans L, Fonollosa V, Solans R, Selva A, Villar M et al. Mortality and prognostic factors in Spanish patients with systemic sclerosis. Rheumatology 2003; 42: 71-5.

18. Hill CL, Nguyen AM, Roder D, Roberts-Thompson P. Risk of cancer in patients with scleroderma: a population based cohort study. Ann Rheum Dis 2003; 62: 728-31.

19. Peters-Golden M, Wise RA, Hochberg M, Stevens MB, Wigley FM. Incidence of lung cancer in systemic sclerosis. J Rheumatol 1985; 12: 1136-9.

20. Pontifex EK, Hill CL, Roberts-Thompson P. Risk facors for lung cancer in patients with scleroderma: a nested case-control study. Ann Rheum Dis 2007; 66: 551-3.

21. Roumm AD, Medsger TA. Cancer and systemic sclerosis. Arthritis Rheum 1985; 28: 1336-40.

22. Launay D, Le Berre R, Hatron PY, Peyrat JP, Hachulla E, Devulder B, Hebbar M. Association between systemic sclerosis and breast cancer: eight cases and review of the literature. Clin Rheumatol 2004; 23: 516-22. 